\title{
Application of Scanning Tunneling Microscope to Metal Fatigue
}

Saburo MATSUOKA

\section{1. はじめに}

走査トンネル顕微鏡（STM）は新しい装置で, 最初 の論文が発表されてから 7 年しかたっていない1).一方, 金属疲労の研究は 100 年以上たっているが，未解決な 部分が多く, 現在でも破壊事故の主因となっている2). 本報告では疲労破壊研究への STM の応用の可能性につ いて述べる.

\section{2. 疲 労 破 壊}

Fig. 1 のように, 荷重を負荷すると, 試験片表面には すべり変形により新生面が生じる，同時に新生面には酸 素や水分子が吸着し，酸化が進む．荷重除荷では逆すべ りが起こるが, 新生面の酸化のために変形の不可逆性が 生じる ${ }^{3)}$. 荷重を繰り返すと, 不可逆変形が累積し, 疲 労き裂が発生する.

Fig. 2 は 5083-0 アルミ合金の疲労特性を $80 \%$ RH(相 対湿度）の湿潤大気と $0.0003 \% \mathrm{RH}$ の乾燥大気中で調 べた結果である4). 大気のような温和な環境下でも疲労 特性は湿度に依存し, 平滑と切久き丸棒試験片ともに疲

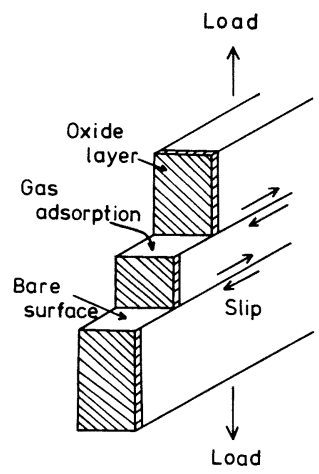

Fig. 1. Schematic illustration of slip deformation at specimen surface.
労寿命は湿潤大気中のほうが短いことがわかる．また， 真空, 海水, 高温などの異なる環境下では疲労特性が異 なることは知られている.

したがって, 疲労破壊の研究においては従来から検討 が多くされてきたすべり変形などの形状変化の観察と同 時に新生面の酸化の評価が重要であると考えられる。こ の点, STM は顕微鏡と分析装置の両方の能力を有し, 種々の環境で使用できるので, 疲労メカニズムの解明に 対して極めて有力な武器と成りえる可能性がある.

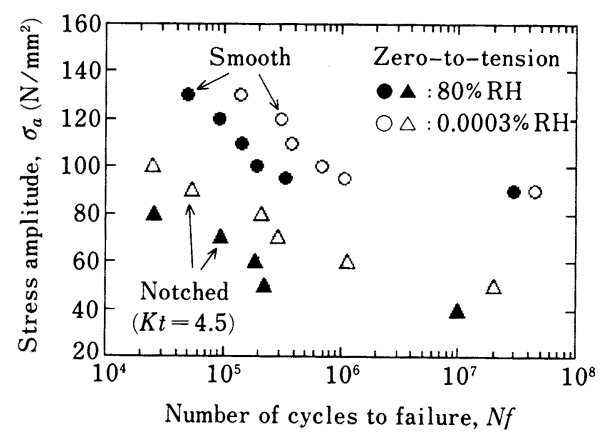

Fig. 2. S-N diagram for 5083-0 aluminium alloy.

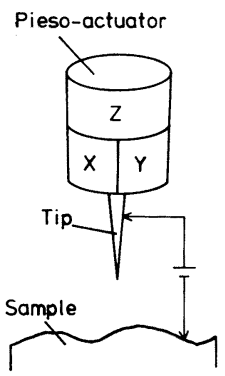

Fig. 3. Schematic illustration of Scanning Tunneling Microscope (STM).

平成元年 1 月 30 日受付（Received Jan. 30,1989）（依頼技術トピックス）

* 金属材料技術研究所 工博 (National Research Institute for Metals, 2-3-12 Nakameguro Meguro-ku, Tokyo 153)

Key words : scanning tunneling microscope; metallic materials; fatigue; slip ; oxidation. 


\section{3. 走査トンネル顕微鏡（STM）}

\section{$3 \cdot 1$ 原理}

Fig. 3 に示すように, STM では電気伝導体（探針）絶緣体-電気伝導体（試料）の間に数十 $\mathrm{mV}$ の電圧を負 荷してトンネル電流を測定することを基本としてい

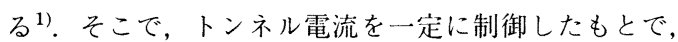
高性能のピエゾアクチュエータで探針を $X$ と $Y$ 方向に 走査し, $Z$ 方向の変位を測定すると, 試料表面の形状 を原子レベルの分解能で観察することができる．一方， $Z$ 方向の変位を固定したもとで，バイアス電圧を変え てトンネル電流を測定すると分析が可能となる.さらに, 絶縁体としては真空のみならず大気, 純水, オイル, 液 体へリウムなどが対象となるため，多くの環境下で測定 ができる。このように，走査型電子顕微鏡（SEM）な どの従来の装置に比べて STM は優れた特徵を有してい る。しかし，探針と試料表面の間隔を数十 $\mathrm{nm}$ とする必 要があるため, 試料表面が厚い酸化物で覆われていると 観察不可能になる欠点がある.

\section{$3 \cdot 2$ 観察結果}

STM を疲労メカニズムの解明に応用する第一歩とし て, 各種金属の研磨面，すべり面，破面を STM で観察 した結果を示す。観察は定電流モードのもとで大気中で 行った (トンネル電流 $=1 \mathrm{nA}$, バイヤス電圧 $=15 \mathrm{mV})$. $3 \cdot 2 \cdot 1$ 研磨面

疲労過程を STM で調べるには, 通常のバフ研磨面や 電解研磨面で安定な観察ができることが出発点となる.

Fig. 4 に純鉄のバフ研磨面の STM 像を示す. 最終仕上 げは $0.05 \mu \mathrm{m}$ のアルミナで行ったが，このアルミナの 粒径に対応した凹凸が観察できた．Table 1 には 8 種類 の純金属と 3 種類の実用金属で観察した結果をまとめて あるが, 白丸印は Fig. 4 と同様な像が得られ, 観察可 能であったことを示し, 黒丸印は $Z$ 方向の変位が不規 則に変化し，安定な像が得られなかったことを示してい る。また，銅の場合にはバフ研磨後にりん酸液中で電解

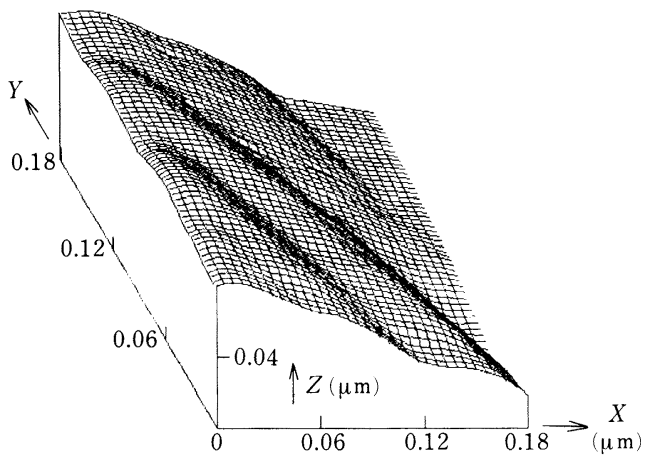

Fig. 4. STM image of specimen surface polished by alumina of $0.05 \mu \mathrm{m}$ for iron.
研磨を行ったが, アルミナによる凹凸が消え, 平坦な面 が観察できた。なお，バフと電解研磨においてはともに 試料表面に酸化膜が形成されることから, 観察叮能な場 合でも酸化膜の影響は存在することになる。

$3 \cdot 2 \cdot 2$ すべり面

Fig. 5 に金のバフ研磨面に曲げで導入したすべりス テップの STM 像を示す。 $X$ 軸に平行にほぼ $0.3 \mu \mathrm{m}$ の 凹凸が観察できるが，これは最終バフ仕上げに前に 0.3 $\mu \mathrm{m}$ のアルミナで研磨した傷と対忍している。一方，斜

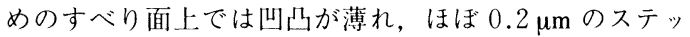
プが形成されていた。

Fig. 6 と Photo. 1 は銅の多重すべりを STM と SEM

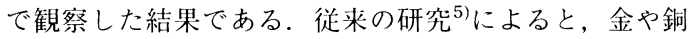
のような fcc 金属ではひずみ量が増すと,すべり間隔は 約 $2 \mu \mathrm{m}$ ，ステップ量は約 $0.2 \mu \mathrm{m}$ で飽和する. 同様な 寸法は Fig. 5 と 6 の STM 像でも得られている.

Fig. 7 と 8 は bcc 金属の鉄, hcp 金属の亜鉛のすべり 面の STM 像である。これらのすべり面の観察結果は Table 1 にまとめたが, とくにアルミニウムでもバフ研 磨面に金蒸着を行うことによってすべり面の観察は叮能

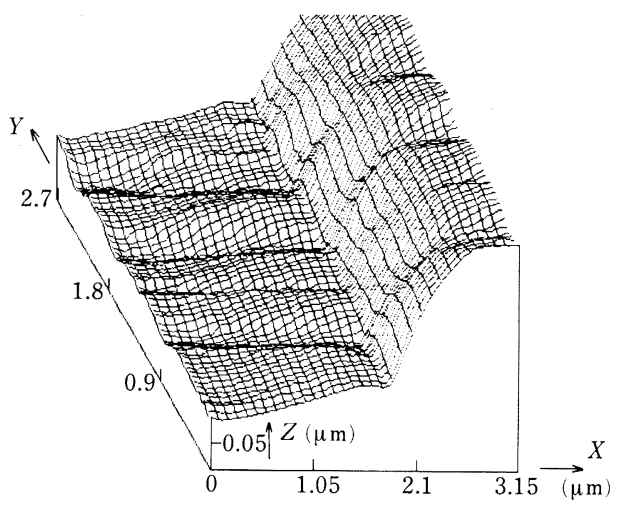

Fig. 5. STM image of single-slip for gold.

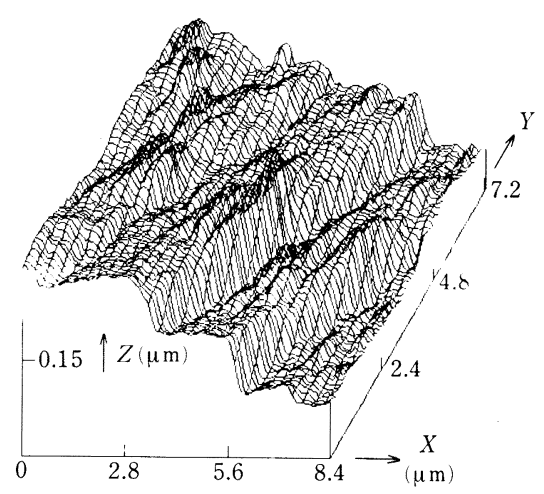

Fig. 6. STM image of multi-slip for copper. 


\section{となる。}

したがって, すべり変形は疲労破壊の初期過程である ことを考えると, STM を疲労研究に応用できる可能性 は大きいことがわかる. さらに, 今後すべり面上の酸化 が STM により評価できるようになると, 第 2 章で述べ た逆すべりに及ぼす酸化の影響などに関する新しい知見 が得られることが期待できる。これに関しては，すでに $\mathrm{Ni}$ (100) 面上の $\mathrm{NiO}$ 酸化物の存在を STM で分析した 結果が報告されている ${ }^{6)}$. また, 応力腐食割れやぜい性 破壊もすべり変形を伴うので, これらの破壊現象に STM を応用できる可能性は大きい.

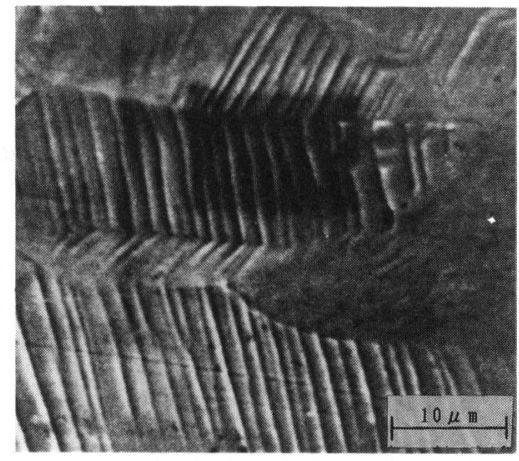

Photo. 1. SEM micrograph of multi-slip for copper.

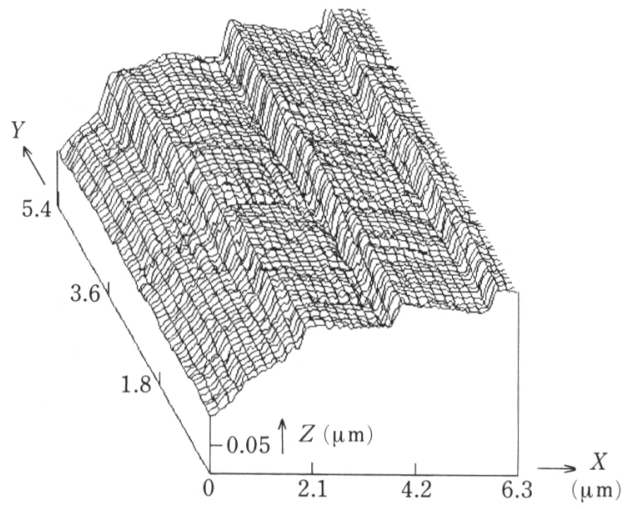

Fig. 7. STM image of multi-slip for iron.

\section{$3 \cdot 2 \cdot 3$ 破面}

$\mathrm{STM}$ による破面観察は SUS304 鋼と Ti-6Al-4V チ タン合金の疲労破面とクロムのぜい性破面で行ったが, ここでは特徴ある結果の得られたクロムのぜい性破面に ついて示す.

Fig. 9 の STM 像で左下から右上に延びているステッ プはリバーパターンに対応するものと考えられる.また, Photo. 2 の SEM 観察では平坦であると思われる破面上 にも STM 観察では小さな山凸があることがわかる.こ のように, STM は従来不足していた高倍率でのフラク トグラフィを集積するのにも役立つ可能性がある。

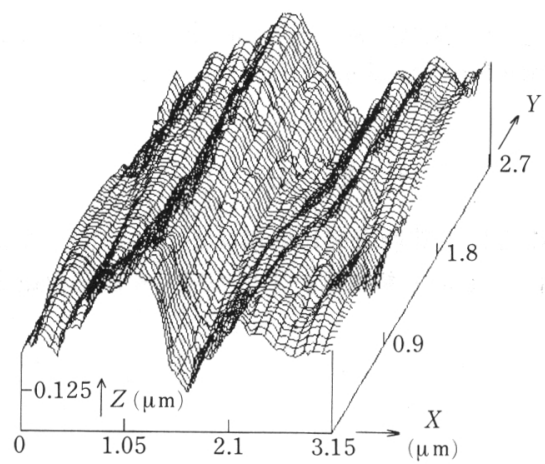

Fig. 8. STM image of multi-slip for zinc.

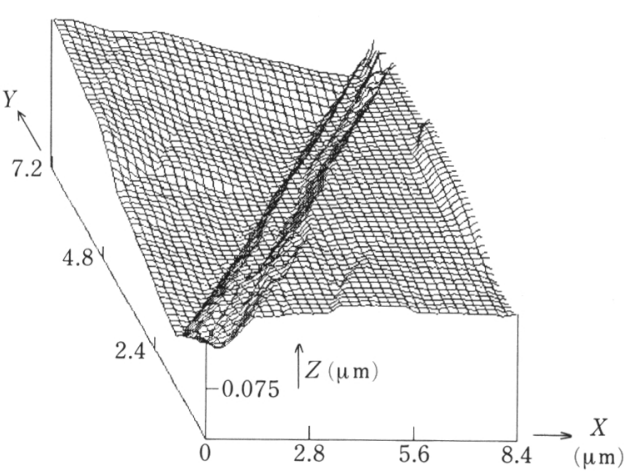

Fig. 9. STM image of brittle fracture surface for chromium.

Table 1. Summary of STM observation.

\begin{tabular}{|c|c|c|c|c|c|c|c|c|c|c|c|}
\hline \multirow{2}{*}{$\begin{array}{l}\text { Surface } \\
\text { conditions }\end{array}$} & \multicolumn{8}{|c|}{ Pure metals } & \multicolumn{2}{|c|}{ Steels } & \multirow{2}{*}{$\begin{array}{c}\text { Alloy } \\
\text { Ti-6Al-4V }\end{array}$} \\
\hline & $\mathrm{Au}$ & $\mathrm{Cu}$ & $\mathrm{Pb}$ & $\mathrm{Ni}$ & $\mathrm{Fe}$ & $\mathrm{Cr}$ & $\mathrm{Zn}$ & $\mathrm{Al}$ & SUS 304 & SB 42 & \\
\hline $\begin{array}{l}\text { Alumina polished } \\
\text { Electro. polished } \\
\text { Slip } \\
\text { Fracture }\end{array}$ & $\frac{0}{0}$ & 8 & $\underline{-}$ & $\frac{0}{0}$ & $\frac{0}{0}$ & $\frac{-}{-}$ & $\frac{0}{0}$ & $\frac{0}{0}$ & $\frac{\bigcirc}{\bigcirc_{F}}$ & $\frac{0}{0}$ & $\frac{-}{\overline{O F}}$ \\
\hline
\end{tabular}




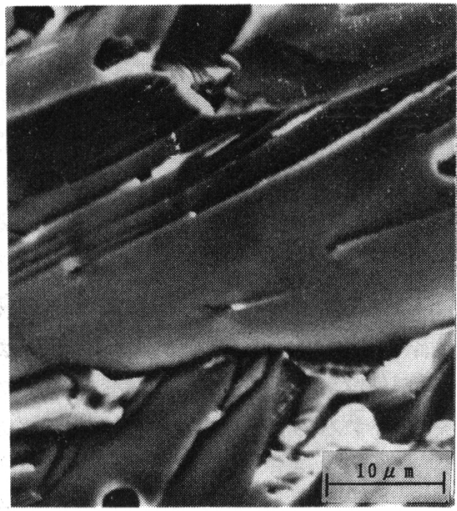

Photo. 2. SEM micrograph of brittle fracture surface for chromium.

\section{4. 終わりに}

STM を疲労破壊研究に応用することに関しては，す ベり面（すなわち新生面）上での吸着や酸化反応を分析
することをはじめとして解決すべき問題は多くあるが, 極めて有望である。また，材料が宇宙などの極限環境下 で使用される機会が増えることを考えると，今後の疲労 をはじめとした破壊研究の方向としては, 力学と物理や 化学などの異分野との境界領域における基礎研究を推進 すべきであると考える.STM は顕微鏡と分析装置の両 方の能力を有しているので,この方向の研究に適してお り，積極的に導入する必要があると思う.

\section{文献}

1 ) G. Binning, $H$. Roher and $E$. Weibel: Physical Review Letter, 49 (1982), p. 57

2 ) 総合材料強度講座 6 , 疲労強度学 (西谷弘信編) (1984) [オーム社]

3 ) F. E. Fujita: Fracture of Solids, 20 (1963), p. 657

4 ) S. Matsuoka, S. Nisijima and H. Hirukawa: Proc. 4 th Int. Conf. on Aluminium Weldments, Tokyo (1988), p. 3

5 ) B. JAOUL: 金属の塑性 (1969) [丸善]

6 ) G. Binning and $H$. Rohrer: IBM J. Res. Develop., 30 (1986), p. 355 